\title{
ANALISIS EFISIENSI BIAYA PRODUKSI DENGAN PENGGUNAAN BIAYA STANDAR DALAM MENINGKATKAN RASIO NET PROFIT MARGIN (STUDI EMPIRIS PADA UMKM DENDENG SAPI DI BANDA ACEH)
}

\author{
Oi Sarah Maghfirah*1, Yulia Fitri ${ }^{* 2}$ \\ 1,2Program Studi Akuntansi Fakultas Ekonomi dan Bisnis Universitas Syiah Kuala \\ e-mail: oyi.sarah@gmail.com ${ }^{* 1}$, yfitri.fekon@ unsyiah.ac.id ${ }^{* 2}$
}

\begin{abstract}
The purpose of this research is to analyze the efficiency of production cost with the use of standard costing. To see if there are some differences between the application of the standar costing and actual costing. Futhermore, this research also seek the option value of the net profit margin ratio in MSMEs of dendeng sapi in Banda Aceh. This research use descriptive statistical analysis to analyze the data. Population in this research are MSMEs listed in Dinas Koperasi dan UMKM Kota Banda Aceh. Based on certain criterias, there are 3 MSMEs as the samples of the research. The research show that standard costing can efficiently the production costs, the difference between the standard costing and the actual production costs that occur is favourable. Based on the results of correlation test there is positive significant correlation between the efficiency of production costs and net profit margin
\end{abstract}

Keywords: Standard costing, efficiency of production cost, and net profit margin ratio.

\section{Pendahuluan}

Usaha Mikro Kecil dan Menengah (UMKM) merupakan badan usaha yang sangat berkembang di Indonesia. UMKM sangat membantu pemerintah dalam meningkatkan pertumbuhan perekonomian masyarakat dengan mengurangi angka pengangguran. Semakin banyak UMKM yang berdiri, maka akan semakin banyak lapangan kerja baru yang tersedia. Dalam UUD RI, Usaha Mikro Kecil dan Menengah (UMKM) merupakan usaha ekonomi produktif yang didirikan oleh perorangan atau badan dan bukan anak cabang dari perusahaan lain. UMKM mempunyai peranan yang sangat penting dalam pertumbuhan perekonomian masyarakat (UUD RI Nomor 20 Tahun 2008).

Tujuan pendirian usaha adalah untuk mendapatkan laba guna meningkatkan kesejahteraan hidup. Sama halnya dengan UMKM yang bertujuan untuk mendapatkan keuntungan dari setiap penjualan atas produk yang dihasilkan, agar dapat meningkatkan kesejahteraan perekonomian. Berdasarkan tujuan tersebut, perkembangan UMKM di Indonesia terus mengalami peningkatan setiap tahunnya. Data yang diperoleh dari Kementrian Koperasi dan Usaha Kecil Menengah Repulik Indonesia menunjukkan bahwa pada tahun 2013, UMKM yang ada di Indonesia sudah mencapai 57.895.721 unit (www.depkop.go.id). Angka tersebut menunjukkan besarnya minat masyarakat Indonesia dalam mendirikan usaha yang mandiri untuk meningkatkan kesejahteraan perekonomian.

Seiring dengan perkembangan usaha yang tumbuh dengan pesat, persaingan yang terjadi di lingkungan bisnis pun semakin ketat, terutama pada usaha yang sejenis. Oleh karena itu, perusahaan harus mampu bertahan serta dituntut untuk siap menghadapi persaingan pasar. Khususnya perusahaan kecil yang harus memiliki upaya pengendalian biaya produksi yang efisien agar menghasilkan produk yang berkualitas dengan biaya yang rendah (Palupi et al., 2016).

Pengendalian biaya produksi dapat dilihat dengan membandingkang hasil yang dicapai dengan hasil yang diharapkan oleh perusahaan. Salah satu tolok ukur yang digunakan untuk mengendalikan biaya produksi pada perusahaan adalah biaya standar. "Biaya standar adalah biaya yang telah ditentukan sebelumnya untuk memproduksi satu unit atau sejumlah produk tertentu pada suatu periode tertentu" (Carter, 2009, p. 158).

Biaya standar yang telah ditetapkan memiliki tujuan untuk mengetahui selisih biaya yang terjadi. 
Sehingga saat terjadi selisih yang merugikan, manajer dapat bertindak cepat dan sesuai untuk dapat mengatasi hal tersebut. Guna kepentingan pengendalian biaya produksi, penting bagi perusahaan untuk mengadakan identifikasi selisih yang terjadi antara biaya standar yang telah ditetapkan dengan biaya yang sesungguhnya terjadi. Apabila biaya yang sesungguhnya terjadi memiliki angka yang lebih kecil daripada biaya standar yang ditetapkan berarti selisih yang dihasilkan merupakan selisih yang menguntungkan (favourable). Namun bila biaya yang sesungguhnya terjadi memiliki angka yang lebih besar dari biaya standar yang ditetapkan, maka selisih yang dihasilkan merupakan selisih yang merugikan (unfavourable) (Edison \& Sapta, 2010).

Selain untuk mengefisiensi biaya produksi dengan penggunaan biaya standar, efektifitas dan efisiensi dalam menjalankan operasional perusahaan juga sangat penting. Efisiensi dalam strategi pemasaran dilakukan dengan perhitungan dan pertimbangan yang tepat sehingga tidak terjadi pemborosan biaya. Efektifitas dalam pemilihan strategi yang tepat sesuai sasaran pasar yang telah ditetapkan perusahaan dapat tercapai. Untuk mengukur efisiensi aktivitas suatu perusahaan dan kemampuan perusahaan memperoleh keuntungan dapat diukur dengan menggunakan rasio net profit margin (Tompodung, 2014).

Rasio net profit margin adalah rasio yang digunakan untuk menunjukan kemampuan perusahaan dalam menghasilkan keuntungan bersih setelah dipotong pajak. Semakin besar rasio ini, maka dianggap semakin baik kemampuan perusahaan untuk mendapatkan laba yang tinggi. Rasio net profit margin yang tinggi menunjukkan bahwa perusahaan mampu mengendalikan biaya yang dikeluarkan untuk memproduksi barang (Riyanto, 2010, p. 39). Berdasarkan hal tersebut, maka dapat diketahui bahwa dengan adanya penggunaan biaya standar maka perusahaan akan berusaha untuk menekan biaya produksi agar lebih efisien. Apabila biaya produksi dapat ditekan, maka akan mampu meningkatkan rasio net profit margin.

Sebagaimana telah dijelaskan pada paragrafparagraf sebelumnya, pertumbuhan UMKM yang pesat juga terjadi di wilayah Aceh. Berdasarkan perolehan data pada tahun 2016 kondisi usaha di Aceh menunjukkan telah terbentuknya usaha mikro sebesar
$71 \%$, usaha kecil sebesar $27 \%$, dan usaha menengah sebesar 2\%. Usaha-usaha tersebut terdiri atas: pertambangan sebanyak 385 unit, peternakan sebanyak 1.117 unit, pertanian sebanyak 1.186 unit, transportasi sebanyak 1.582 unit, industri sebanyak 23.816 unit, dan perdagangan sebanyak 45.968 unit. Berdasarkan data tersebut dapat dilihat bahwa industri dan perdagangan merupakan usaha yang paling banyak dilakukan oleh masyarakat Aceh (www.diskop.acehprov.go.id).

Sayangnya, perkembangan UMKM yang terjadi tidak diimbangi dengan informasi yang jelas mengenai efisiensi produksi yang ada pada UMKM tersebut. Informasi tentang efisien atau tidaknya produksi hanya akan didapat bila melakukan observasi secara langsung pada UMKM tersebut. Karena hal tersebut, penulis melakukan studi empiris pada beberapa UMKM dendeng sapi yang ada di Banda Aceh. Penulis memilih 3 UMKM dendeng sapi yang sesuai dengan kriteria sampel untuk melihat bagaimana efisiensi biaya produksi yang dilakukan oleh pemilik usaha agar tetap bisa aktif berproduksi. Berdasarkan data yang diperoleh, terdapat perbedaan harga jual pada 3 UMKM tersebut. Berikut harga dari setiap UMKM dendeng sapi tersebut untuk per kg:

UMKM Gunung Seulawah dan Rencong Aceh memiliki harga jual yang sama yaitu Rp 240.000 Sedangkan UMKM Bungong Jaroe memiliki harga jual Rp 220.000. Hal ini mengindikasikan bahwa UMKM dendeng sapi tersebut dapat mengendalikan setiap biaya produksi yang dikeluarkan sehingga mampu mematok harga jual yang tepat berdasarkan biaya yang dikeluarkan.

Salah satu upaya yang harus digunakan oleh usaha UMKM dendeng sapi untuk mendukung efisiensi biaya produksi adalah dengan adanya penerapan biaya standar. Dengan adanya perhitungan biaya standar yang dilakukan maka setiap perusahaan memiliki batasan-batasan biaya yang harus dikeluarkan dan tidak boleh dikeluarkan oleh perusahaan. Dengan demikian, setiap perusahaan berkesempatan untuk dapat bersaing dari usaha-usaha yang sejenis tanpa menurunkan kualitas produk.

Berdasarkan pemaparan di atas, biaya standar sangat berperan penting dan membantu untuk mengendalikan aktivitas produksi, juga membantu perusahaan dalam merencanakan dan mengefisiensi 
biaya produksi yang berkaitan dengan peningkatkan laba agar lebih optimal.

Penelitian ini bertujuan untuk mengetahui apakah penggunaan biaya standar mampu mengefisienkan biaya produksi pada UMKM Gunung Seulawah, Bungong Jaroe, dan Rencong Aceh, bagaimana rasio net profit margin pada UMKM Gunung Seulawah, Bungong Jaroe, dan Rencong Aceh, serta melihat hubungan antara efisiensi biaya produksi dengan rasio net profit margin pada UMKM Gunung Seulawah, Bungong Jaroe, Rencong Aceh.

\section{Kerangka Teoritis}

\section{Biaya}

Biaya adalah kas atau nilai ekuivalen kas yang dikorbankan untuk mendapatkan barang atau jasa yang akan datang bagi organisasi (Hansen \& Mowen, 2013, p. 36). Menurut Mursyidi (2010, p. 14), biaya adalah suatu pengorbanan yang dapat mengurangi kas atau harta lainnya untuk mencapai tujuan, baik yang dapat dibebankan pada saat ini maupun pada saat yang akan datang.

\section{Biaya Produksi}

Mulyadi (2009, p. 14) biaya produksi adalah biaya-biaya yang terjadi untuk mengolah bahan baku menjadi produk jadi yang siap untuk dijual. Biayabiaya tersebut yaitu biaya bahan baku, biaya bahan penolong, biaya gaji karyawan, biaya depresiasi mesin, dan biaya lain baik yang langsung maupun tidak langsung berhubungan dengan proses produksi.

\section{Biaya Standar}

Menurut Mulyadi (2009, p. 387) biaya standar adalah biaya yang ditentukan di muka, yang merupakan jumlah biaya yang seharusnya dikeluarkan untuk membuat satu satuan produk atau untuk membiayai kegiatan tertentu, di bawah asumsi kondisi ekonomi, efisiensi, dan faktor-faktor lainnya.

\section{Manfaat Penetapan Biaya Standar}

Raiborn \& Kinney (2011, p. 356) menyatakan bahwa sistem biaya standar didesain untuk memperkenankan manajer merencanakan biaya yang akan terjadi dalam menjalankan aktivitas produksi atau jasa, mengumpulkan informasi atas biaya aktual yang terjadi, dan memperkenankan manajer untuk mengontrol operasi dengan membandingkan perkiraan biaya dengan biaya aktual serta mengevaluasi kinerja berdasarkan pada ukuran dan perencanaan suatu periode.

\section{Analisis Varians}

Horngren et al., (2008, p. 262) mengartikan varians sebagai perbedaan antara jumlah yang didasarkan pada hasil aktual dan jumlah yang dianggarakan. Ada dua varians dalam melakukan pengukuran kinerja, yaitu:

1) Efektivitas, yaitu tingkat pencapaian tujuan atau sasaran yang telah ditetapkan sebelumnya. Misalnya penjualan, kepuasan pelanggan, dan kualitas dari produk yang dibuat.

2) Efisiensi, yaitu jumlah relatif input yang digunakan untuk mencapai tingkat output tertentu. Semakin sedikit kuantitas input yang digunakan untuk membuat sejumlah produk atau semakin banyak produk yang dibuat dengan kuantitas input tertentu, maka semakin tinggi efisiensinya.

Garrison et al., (2013, p. 8) membagi varians kedalam dua golongan, yaitu:

1) Varians harga, yaitu perbedaan antara harga input aktual dan harga standarnya, dikalikan dengan jumlah aktual input yang dibeli.

2) Varians kuantitas, yaitu perbedaan antara banyaknya input aktual yang digunakan dan banyaknya input yang seharusnya digunakan dengan mengginakan harga standar input.

\section{Efisiensi Biaya Produksi}

Efisiensi produksi adalah jumlah relatif input yang digunakan untuk mencapai tingkat output tertentu. Semakin sedikit kuantitas input yang digunakan untuk membuat sejumlah produk atau semakin banyak produk yang dibuat dengan kuantitas input tertentu, maka semakin tinggi efisiensinya (Horngren et al., 2008, p. 279). Efisiensi biaya produksi adalah efisiensi biaya atau menekan biaya yang digunakan atas bahan baku, tenaga kerja, dan overhead untuk proses produksi. Efisiensi biaya produksi merupakan hal penting bagi perusahaan untuk mencapai laba yang optimal. Tingkat efisiensi biaya produksi suatu perusahaan dapat diukur dengan berapa biaya bahan baku, tenaga kerja langsung, dan overhead pabrik yang digunakan untuk menghasilkan keluaran tertentu (Palupi et al., 2016). 


\section{Rasio Net Profit Margin (NPM)}

Kasmir (2012, p. 200), mengartikan net profit margin sebagai ukuran keuntungan dengan membandingkan antara laba setelah bunga dan pajak dibandingkan dengan penjualan untuk melihat pendapatan bersih perusahaan atas penjualan. Rasio net profit margin yaitu rasio yang menunjukkan berapa bagian dari penjualan bersih yang menjadi laba setelah bunga dan pajak (Riyanto, 2010, p. 38)

Rasio ini dihitung untuk menunjukkan tingkat laba bersih perusahaan terhadap total penjualan. Semakin tinggi rasio ini, maka semakin tinggi pula keuntungan yang didapat oleh perusahaan.

\section{Metode Penelitian}

\section{Desain dan Jenis Penelitian}

Jenis penelitian yang digunakan dalam penelitian ini adalah studi empiris. Studi empiris merupakan studi yang dilakukan dapat diamati oleh indera manusia, sehingga orang lain pun mampu mengamati dan mengetahui studi yang digunakan (Sugiyono, 2014, p. 2).

\section{Populasi dan Sampel Penelitian}

Populasi dalam penelitian ini adalah UMKM dendeng sapi di Banda Aceh yang tercatat pada Dinas Koperasi dan Usaha Mikro Kecil Menengah Kota Banda Aceh. Data yang diperoleh, ada 13 UMKM dendeng sapi yang terdaftar. Namun setelah penulis melakukan survei, hanya 5 UMKM dendeng sapi yang ada. Pemilihan sampel dalam penilitian ini berdasarkan purposive sampling dengan kriteria sebagai berikut:

1) UMKM dendeng yang memproduksi dendeng sapi.

2) UMKM dendeng sapi yang berproduksi secara rutin atau aktif setiap bulan.

3) UMKM dendeng sapi yang memiliki penetapan biaya standar produksi.

\section{Sumber dan Teknik Pengumpulan Data}

Sumber data primer diperoleh secara langsung dengan mewawancarai pemilik UMKM dendeng sapi yang menjadi sampel pada penelitian ini. Sedangkan data sekunder mengenai perkembangan UMKM di Indonesia diperoleh dari situs resmi Departemen Koperasi dan Usaha Kecil Menengah Indonesia dan data jumlah UMKM di Banda Aceh diperoleh dari kantor serta situs resmi Dinas Koperasi dan UMKM Banda Aceh.

Teknik yang dilakukan untuk mengumpulkan data penelitian adalah sebagai berikut:

1) Penelitian lapangan, yakni melakukan peninjauan dan pengamatan secara langsung terhadap objek yang diteliti, dengan melakukan wawancara pada pemilik UMKM Gunung Seulawah, Bungong Jaroe, dan Rencong Aceh.

2) Tinjauan kepustakaan, yakni membaca serta mempelajari buku-buku ataupun literatur yang mendukung dan berkaitan dengan topik penelitian. Hal ini bertujuan untuk mendapatkan dasar teoritis yang digunakan dalam penelitian dan memberikan tambahan wawasan bagi peneliti dalam melakukan penelitian.

\section{Instrumen Penelitian}

Instrumen yang digunakan dalam penelitian ini adalah kuesioner sebagai pedoman wawancara yang ditujukan kepada pemilik UMKM dendeng sapi.

\section{Metode Analisis Data}

Metode analisis data yang digunakan dalam penelitian ini adalah analisis statistik deskriptif. Analisis statistik deskriptif adalah statistik yang digunakan untuk menganalisis data dengan cara mendeskripsikan atau menggambarkan data yang telah terkumpul tanpa bermaksud membuat kesimpulan yang berlaku umum (Sugiyono, 2014, p. 206).

Tahapan yang dilakukan dalam menganalisis data yang diperoleh dalam penelitian ini adalah, sebagai berikut:

1) Menghitung selisih antara biaya standar dengan biaya aktual dengan menggunakan rumus sebagai berikut:

$$
\mathrm{ei}=\mathrm{Xi}-\mathrm{Fi} \ldots \text { (1) }
$$

ei $=$ Selisih

$\mathrm{Xi}=$ Data aktual ke $\mathrm{i}$

$\mathrm{Fi}=$ Data standar ke i

(Makridakis et al, 2008, p. 70)

2) Menghitung tingkatan efisiensi biaya produksi menggunakan rumus:

$\%=(\mathrm{n} / \mathrm{N}) \times 100 \%$

$\mathrm{n}=$ Selisih (ei)

$\mathrm{N}=$ Nilai standar

(Subagyo, 2011, p. 31). 
3) Menghitung rasio net profit margin menggunakan rumus:

NPM=Laba bersih/Penjualan....(3)

4) Menguji correlation test antara efisiensi biaya produksi dengan rasio net profit margin dengan menggunakan aplikasi SPSS 24.

\section{Hasil Penelitian}

Pada penelitian ini, penulis membahas tentang analisis efisiensi biaya produksi dengan penggunaan biaya standar dalam meningkatkan rasio net profit margin. Dimana pada setiap UMKM yang menjadi bahan analisis adalah biaya standar, biaya produksi aktual serta penjualan atas dendeng sapi. Sampel penelitian yang diambil pada penelitian ini adalah 3 UMKM dendeng sapi yaitu Gunung Seulawah, Bungong Jaroe, dan Rencong Aceh.

UMKM Gunung Seulawah yang berlokasi di Simpang Surabaya memproduksi beberapa macam dendeng yakni dendeng sapi, dendeng ikan, dan dendeng rusa. Sedangkan UMKM Bungong Jaroe yang berlokasi di Setui dan UMKM Rencong Aceh yang terletak di Lamseupeung hanya memproduksi satu jenis dendeng saja yaitu dendeng sapi.

\section{Biaya Standar Produksi}

1) Biaya Standar Bahan Baku

Biaya standar bahan baku pada penelitian ini sesuai dengan harga pasaran yang berlaku di daerah Aceh.

2) Biaya Standar Tenaga Kerja Langsung

Biaya standar tenaga kerja pada penelitian ini sesuai dengan Upah Minimum Provinsi (UMP) Aceh pada tahun 2017 yaitu sebesar Rp 2.500.000. Dimana waktu kerja adalah 7 jam per hari atau 40 jam per minggu untuk sistem kerja 6 hari per minggu (Peraturan Gubernur Aceh Nomor 72 Tahun 2016).

3) Biaya Standar Overhead Pabrik

Biaya standar overhead pabrik sesuai dengan harga pasaran dan kebutuhan akan bahan dan alat pada setiap UMKM.

\section{Biaya Standar Produksi UMKM Gunung Seulawah}

Jumlah biaya standar bahan baku yang digunakan untuk memproduksi dendeng sapi membutuhkan biaya standar bahan baku yang berbedabeda dibeberapa bulan. Pengeluaran yang harus dikeluarkan pemilik usaha pada bulan Januari sampai
April adalah Rp 559.687.500 setiap bulannya. Pada bulan Mei hingga Agustus biaya standar bahan baku yang harus dikeluarkan adalah Rp 590.625.000 setiap bulannya. Sedangkan pada bulan September hingga Desember biaya standar yang harus dikeluarkan untuk setiap bulannya adalah Rp 646.562.500. Jumlah biaya standar tenaga kerja langsung yang harus dikeluarkan oleh UMKM Gunung Seulawah untuk memproduksi dendeng sapi setiap bulannya adalah sebesar Rp 22.500.000. Sedangkan untuk biaya overhead pabrik standar setiap bulannya pada tahun 2017 adalah sebesar Rp 32.457.166.

\section{Biaya Standar Produksi UMKM Bungong Jaroe}

Jumlah biaya standar bahan baku yang digunakan untuk memproduksi dendeng sapi pada bulan Januari hingga April adalah sebesar Rp 221.880.000 setiap bulannya. Biaya standar untuk bulan Mei hingga bulan Agustus adalah Rp 234.205.000 untuk setiap bulannya. Sedangkan untuk bulan September hingga Desember biaya standar bahan baku setiap bulannya adalah sebesar Rp 246.525.000. Jumlah biaya standar gaji tenaga kerja langsung yang harus dikeluarkan oleh UMKM Bungong Jaroe untuk memproduksi dendeng sapi setiap bulannya adalah sebesar Rp 17.500.000. Sedangkan untuk biaya overhead pabrik standar setiap bulannya pada tahun 2017 adalah sebesar Rp 31.424.640.

\section{Biaya Standar Produksi UMKM Recong Aceh}

Jumlah biaya standar bahan baku yang digunakan untuk memproduksi dendeng sapi pada bulan Januari hingga April adalah sebesar Rp 25.017.500 setiap bulannya. Biaya standar untuk bulan Mei hingga bulan Agustus adalah Rp 27.158.000 untuk setiap bulannya. Sedangkan untuk bulan September hingga Desember biaya standar bahan baku setiap bulannya adalah sebesar Rp 29.293.500. Jumlah biaya standar gaji tenaga kerja langsung yang harus dikeluarkan oleh UMKM Bungong Jaroe untuk memproduksi dendeng sapi setiap bulannya adalah sebesar Rp 7.500.000. Sedangkan untuk biaya overhead pabrik standar setiap bulannya pada tahun 2017 adalah sebesar Rp 944.144. 


\section{Biaya Aktual Produksi UMKM Gunung Seulawah}

Total biaya produksi aktual yang dikeluarkan adalah sebesar $\mathrm{Rp}$ 6.359.290.400 dengan total biaya bahan baku sebesar Rp 5.990.250.000, biaya gaji tenaga kerja langsung sebesar Rp 151.200.000, dan biaya overhead pabrik sebesar Rp 217.840.400.

\section{Biaya Aktual Produksi UMKM Bungong Jaroe}

Total biaya bahan baku sebesar Rp 2.368.268.000, biaya gaji tenaga kerja langsung sebesar Rp 109.200.000, dan biaya overhead sebesar Rp 111.811.900 untuk memproduksi dendeng sapi sebanyak $14.400 \mathrm{~kg}$. Sehingga total biaya produksi aktual yang dikeluarkan adalah sebesar Rp 2.589.279.900.

\section{Biaya Aktual Produksi UMKM Rencong Aceh}

Total biaya untuk bahan baku adalah sebesar Rp 236.575.500, total biaya tenaga kerja langsung adalah sebesar Rp 27.000.000, sedangkan total biaya overhead pabrik sebesar Rp 7.607.800. Total biaya produksi aktual yang dikeluarkan oleh pemilik usaha adalah sebesar Rp 271.183.300.

\section{Penjualan}

Pada tahun 2017, penjualan dari setiap UMKM sangat bervariasi. Angka penjualan yang tinggi terjadi saat Ramadhan, Idul Fitri, Idul Adha serta saat libur panjang. Saat liburan tiba sering kali Aceh kedatangan para wisatawan. Selain souvenir para wisatawan juga mencari makanan khas Aceh sebagai buah tangan. Salah satu makanan khas Aceh yang memiliki rasa yang enak serta tahan lama adalah dendeng sapi. Sehingga saat liburan tiba penjualan dendeng sapi pun mengalami peningkatan. Dari hasil wawancara yang dilakukan, penulis dapat mengetahui terjadinya penjualan yang rendah di setiap UMKM bukanlah karena ketidakmampuan UMKM dalam berproduksi dan memasarkan produk mereka. Hal tersebut terjadi karena pada saat itu kurangnya minat masyarakat Banda Aceh untuk membeli dendeng sapi serta tidak ramai wisatawan yang berkunjung ke Aceh.

\section{Pembahasan}

\section{Selisih biaya standar dengan biaya aktual dan efisiensi biaya produksi}

Setelah memperhitungan tingkat efisiensi biaya produksi dengan mempersentasekan hasil dari selisih antara biaya aktual dengan biaya standar, diperoleh hasil yang dapat dilihat pada Tabel 4.40 di atas, menunjukkan perhitungan biaya standar mampu mengefisiensikan biaya produksi yang dilakukan pada tahun 2017. Berdasarkan atas perhitungan biaya standar yang diperuntukkan untuk UMKM Gunung Seulawah maka dapat dilihat pada tabel bahwa, pemilik usaha sudah mampu mengefisienkan biaya produksi rata-rata $18,7 \%$ dari biaya standar. Pada tabel juga menunjukkan bahwa UMKM Bungong Jaroe sudah mampu mengefisienkan biaya produksi rata-rata 23,7\% dari biaya standar yang telah diperhitungkan sebelumnya. Apabila pemilik usaha UMKM Rencong Aceh melakukan perhitungan biaya stanndar yang sesuai dengan harga pasaran yang berlaku maka pemilik usaha akan mampu mengefisienkan biaya produksi rata-rata sebanyak $36 \%$ dari biaya standar yang telah diperhitungkan oleh penulis pada paragrafparagraf sebelumnya.

Walaupun biaya standar yang ada diperhitungkan oleh penulis, yang mana biaya standar yang berdasarkan harga pasaran yang berlaku pada adaerah Aceh. Hasil perhitungan menunjukkan bahwasanya setiap pemilik usaha dendeng sapi telah mampu mengefisiensikan biaya produksi mereka. Ini dikarenakan para pemilik usaha menyadari bahwasanya bahan baku terus mengalami peningkatan harga, sehingga mereka harus memiliki pilihan atau alternatif agar usaha mereka terus berkembang dan tidak mengalami kerugian. Banyak strategi yang digunkan oleh setiap pemilik usaha dendeng sapi ini. Salah satunya adalah setiap pemilik usaha memilih bahan baku yang mana harganya lebih murah namun mengolah daging terdsebut dengan sangat baik sehingga dendeng yang dihasilkan berkualitas tinggi. Selain itu juga mereka menjalin hubungan kerja sama dengan para distributor bahan baku.

Nilai yang sedang dan rendah yang terdapat pada tabel dikatakan lebih efisien karena harga yang diperoleh pemilik tidak jauh berbeda dari harga pasaran yang beredar atau biaya standar. Namun nilai yang lebih tinggi dikatakan tidak efisien karena harga yang diperoleh berada jauh dari harga standar sehingga dapat dipertanyakan akan kualitas dari bahan yang digunakan, dan tidak dapat dinilai. Manfaat daria adanya penetapan biaya standar sendiri adalah sebagai acuan atau batas untuk pengeluaran biaya yang seharusnya dikeluarkan, walaupun biaya yang 
dikeluarkan lebih besar dari biaya standar yang ditetapkan, apabila jumlahnya sedikit maka itu masih dikatakan efisien. Namun apabila pengeluarannya sangat besar maka itu sudah tidak efisiensi lagi. Sama halnya dengan jumlah yang dikeluarkan tidak lebih besar dari biaya standar, bila jumlah yang dikeluarkan terlalu rendah dari jumlah standar maka kualitas bahan harus diragukan, serta dapat merugikan pihak lain seperti teaga jerja dan lainnya. Sedangkan efisien yang dimaksudkan adalah jumlah yang dikeluarkan tidak tinggi dari jumlah standar yang ada serta tidak terlalu rendah dari jumlah standar tersebut.

\section{Laba Bersih dan Rasio Net Profit Margin}

Berdasarkan Tabel 4.42, 4.43, dan 4.44 dapat diketahui bahwa setiap UMKM dendeng sapi memiliki laba yang berbeda setiap bulannya. Sistem persediaan yang dilakukan oleh setiap UMKM dendeng sapi ialah sistem FIFO (first in first out), sehingga walaupun produk yang terjual memiliki harga tetap dan biaya produksi per unit yang berbeda maka laba yang dihasilkan akan lebih optimal.

Pada Tabel 4.42 dapat dilihat bahwa UMKM Gunung Seulawah memiliki laba yang besar, ini karena Gunung Seulawah membeli bahan baku dengan harga yang sangat mudah yang mana dapat dilihat pada perhitungan biaya produksi sebelumnya. Selain itu juga pemilik usaha memproduksi dendeng sapi dengan jumlah yang tidak sedikit, membuat tingkat penjualannya lebih besar.

Pada tabel 4.43 juga menunjukkan bahwa UMKM Bungong Jaroe memiliki laba yang tidak sedikit dengan jumlah produksi $1.200 \mathrm{~kg}$ setiap bulannya selama tahun 2017. Salah satu alasan mengapa pemilik usaha mendapatkan laba yang besar dikarenakan harga produksi per kilogram setiap dendeng sapi yang dihasilkan memiliki harga yang sedikit rendah. Ini dikarenakan pemilik usaha memilih bahan baku yang baik dengan harga yang rendah. Seperti harga daging yang dibelinya adalah harga daging impor yang ada di Bulog. Dimana diketahui, bahwa Bulog memberikan harga yang murah dari daging impor yang beredar dari pedagang.

Sedangkan keuntungan atau laba yang diperoleh oleh UMKM Rencong Aceh dapat dilihat pada Tabel 4.44. Laba yang dihasilkan oleh UMKM ini sangatlah sedikit, walaupun itu merupakan hal yang wajar, sebagaimana produksi yang dilakukan oleh pemilik usaha hanya $100 \mathrm{~kg}$ setiap bulannya selama tahun 2017. Salah satu faktor penyebab laba yang rendah adalah pemilik usaha memilih bahan baku utama yaitu daging dengan harga yang tinggi, sehingga biaya produksi per kilogram dendeng sapi menjadi tinggi.

Hasil perhitungan rasio net profit margin yang didapat dalam Tabel 4.45 menunjukkan bahwa nilai rasio net profit margin yang diperoleh setiap UMKM bervariasi. Nilai rasio yang diperoleh berada di atas $3 \%$. Rata-rata nilai rasio yang diperoleh UMKM Gunung Seulawah adalah 11\%. UMKM Bungong Jaroe memiliki rata-rata nilai rasio net profit margin sebesar 17\%, sedangkan UMKM Rencong Aceh memiliki nilai rasio net profit margin rata-rata $4 \%$.

\section{Hubungan Efisiensi Biaya Produksi dengan Rasio Net Profit Margin}

Berdasarkan hasil uji correlation test menggunakan SPSS dengan Pearson menunjukkan bahwa bahwa adanya hubungan antara efisiensi biaya produksi dengan rasio net profit margin. Signifikan yang terjadi berada pada 0,01 hal ini menunjukkan bahwa adanya hubungan yang signifikan antara efisiensi biaya produksi dengan rasio net profit margin.

\section{Kesimpulan dan Saran}

Setelah melakukan penelitian tentang biaya standar, biaya produksi, dan penjualan, menghitung selisih antara biaya standar yang ditetapkan dengan biaya aktual produksi yang terjadi, menghitung tingkat efisiensi biaya produksi, menghitung rasio net profit margin, serta melihat perbandingan antara tingkat efisiensi biaya produksi dengan rasio net profit margin, maka dapat disimpulkan bahwa:

1) UMKM Dendeng Sapi tidak memperhitungkan biaya standar, walaupun biaya aktual yang dikeluarkan berada dibawah biaya standar. Pemilik usaha memiliki alternatif dalam memilih bahan baku dengan harga yang lebih murah dari harga pasaran.

2) Hasil perhitungan rasio net profit margin menunjukkan hasil yang bervariasi. Namun dengan penggunaan biaya standar, para pemilik usaha mampu mengurangi biaya produksi sehingga laba yang didapat lebih optimal walaupun penjualan yang terjadi tidak menentu. 
3) Hasil penilaian korelasi antara efisiensi biaya produksi dengan rasio net profit margin menunjukkan adanya hubungan yang positif dan signifikan.

Beberapa keterbatasan yang terdapat dalam penelitian ini. yaitu:

1) Penelitian yang dilakukan hanya mengambil sampel pada 3 UMKM dendeng dan hanya melihat produksi dendeng sapi saja. Hasil yang didapat tidak mampu digeneralisasikan secara umum.

2) Penelitian ini hanya menggunakan data tahun 2017, sehingga kemungkinan akan mendapatkan hasil yang berbeda untuk penelitian pada tahun sebelum dan berikutnya.

3) Data yang diperoleh pada penelitian ini mungkin tidak memiliki tingkat akurasi sebanyak 100\% karena keterbatasan UMKM dalam melakukan pencatatan laporan biaya produksi serta laporan laba-rugi.

4) Laba dari setiap UMKM dendeng sapi dihitung kembali oleh penulis sesuai dengan standar akuntansi, karena perhitungan yang dilakukan oleh pemilik UMKM dendeng sapi tidak sesuai dengan standar akuntansi.

Berdasarkan penelitian yang telah dilakukan, saran yang dapat diberikan adalah sebagai berikut:

1) Para pelaku usaha sebaiknya menata kembali laporan biaya produksi dan laporan laba rugi yang telah ada dengan lebih baik. Selain laporan biaya produksi dan laporan laba rugi, sebaiknya pelaku usaha khususnya UMKM dendeng sapi membuat laporan keuangan walaupun hanya laporan yang sederhana. Laporan keuangan akan sangat membantu dalam memberikan informasi secara jelas mengenai kondisi usaha yang digeluti.

2) Pelaku usaha sebaiknya menerapkan biaya standar sebagai acuan untuk melakukan pengendalian biaya produksi. Apabila UMKM Dendeng Sapi menerapkan biaya standar, sebaiknya pemilik usaha melakukan analisis efisiensi biaya produksi dengan melihat selisih antara biaya aktual dan biaya standar yang ditetapkan tersebut. Sehingga pelaku usaha dapat mengetahui tingkat efisiensi biaya produksi. Selain menganalisis efisiensi biaya produksi, pelaku usaha juga harus mengevaluasi setiap biaya standar yang telah ditetapkan.

3) Bagi penelitian selanjutanya yang meneliti tentang penerapan biaya standar pada UMKM, sebaiknya dapat mengambil sampel penelitian lebih banyak lagi, memperluas ruang lingkup penelitian, dan meneliti lebih jauh tentang kegunaan biaya standar seperti hubungannya dengan kinerja manajer atau karyawan.

\section{DAFTAR PUSTAKA}

Alexandri. (2008). Manajemen Keuangan Bisnis. Edisi 1. Bandung: Alfabeta.

Arly, R. L., \& Sondakh, J. J. (2014). Analisis Varians dalam Penerapana Biaya Standar sebagai Alat Pengendalian Biaya Produksi pada UD Berkat Anugrah Manado. Jurnal EMBA. Vol. 2, No. 3. ISSN: 2303-1174, 570-579.

Badem, A. C., Ergin, E., \& Drury, C. (2013). Is Standard Costing Still Used? Evidence from Turkish Automotive Industry. International Business Research; Vol. 6, No. 7; ISSN 19139004,E-ISSN 1913-9012, 79-90.

Bustami, B., \& Nurlela. (2013). Akuntansi Biaya. Edisi 4. Jakarta: Mitra Wacana.

Carter, W. K. (2009). Akuntansi Biaya. Jakarta: Salemba Empat.

Edison, \& Sapta, U. (2010). Pengaruh Biaya Standar Terhadap Pengendalian Biaya Produksi ( Studi Kasus PT. ITP, Tbk). Jurnal Ilmiah Ranggagading. Vol. 10, No. 2, 120-130.

Fahmi, I. (2014). Analisis Kinerja Keuangan: Panduan bagi Akademisi, Manajer, dan Investor untuk Menilai dan Menganalisis Bisnis dari Aspek Keuangan. Bandung: Alfabeta.

Garrison, R. H., W.Norren, E., \& Brewer, P. C. (2013). Akuntansi Manajerial. Jilid 2. Terjemahan. Jakarta: Salemba Empat.

Hansen, C. T., Datar, S. M., \& Foster, G. (2013). Akuntansi Manajerial. Edisi 8. Jakarta: Salemba Empat.

Harahap, N., \& Vera, D, K. (2008). Pengaruh Efisiensi Biaya Produksi Terhadap Laba Bersih. Jurnal Akuntansi FE USU. Vol. 20, No. 1, ISSN: 0852-1875, 1-9. 
Horngren, C. T., Datar, M., \& Foster, G. (2008). Akuntansi Biaya, Penekanan Manajerial. Jakarta: Erlangga.

Kasmir. (2012). Analisis Laporan Keuangan. Jakarta: PT. Raja Grafindo Persada.

Layaman, \& Nurlatifah. (2016). Strategi Meningkatkan Produksi UMKM di Kabupaten Cirebon Melalui Efektivitas Persediaan Bahan Baku dan Modal Usaha. Jurnal AL-Mustashfa. Vol.4, No.2, 111-123.

Makridakis, S., Wheelwright, S., \& Gee, V. E. (2008). Forecasting: Methods and Applications. New York: Wiley.

Martusa, R., \& Nasa, L. A. (2012). Penerapan Biaya Standar Terhadap Pengendalian Biaya Produksi: Studi Kasus pada CV Sejahtera Bandung. Jurnal Ilmiah Akuntansi. NO. 07. ISSN: 20864159, 1-20.

Massie, N. I., Saerang, D. P., \& Tirayoh, V. Z. (2018). Analisis Pengendalian Biaya Produksi untuk Menilai Efisiensi da Efektivitas Biaya Produksi. Jurnal Riset Akuntansi Going Concern. Vol. 13, No. 3, 355-364.

Megawati, D. L., Saifi, M., \& A, Z. Z. (2016). Analisis Perhitungan Biaya Standar sebagai Salah Satu Pendukung Efisiensi Biaya Produksi (Studi pada Koperasi Serba USaha Brosem Batu pada Tahun 2015). Jurnal Administrasi Bisnis (JAB). Vol. 38, No. 1, 97-105.

Mulyadi. (2009). Akuntansi Biaya. Edisi 5. Yogyakarta: YKPN.

Mursyidi. (2010). Akuntansi Biaya: Conventional Costing, Just In Time, dan Activity Based Costing. Bandung: PT. Refika Aditama.

Palupi, T. A., Z.A, Z., \& NP., M. W. (2016). Analisis Biaya Standar untuk Mendukung Efisiensi Biaya Produksi Perusahaan (Studi pada Pabrik Gula Lestari, Patianrowo, Nganjuk). Jurnal Administrasi Bisnis (JAB), Vol. 36 No. 1, 80-85.

Pratiwi, J. (2013). Penerapan Biaya Standar dalam Pengendalian Biaya Produksi pada PT. Pertani (Persero) Cabang Sulawesi Utara. Jurnal EMBA. Vol. 1, No. 4. ISSN: 2303-1174, 16171626.

Raiborn, A. C., \& Kinney, M. R. (2011). Akuntansi Biaya: Dasar dan Perkembangan. Buku 1. Edisi 7. Terjemahan. Jakarta: Salemba Empat.
Riyanto, B. (2010). dasar dasar pembelanjaan perusahaan, edisi 4. Yogyakarta: BPFE.

Samryn, L. M. (2012). Akuntansi Manajemen, Edisi Revisi. Jakarta: Kencana.

Sekaran, U., \& Bougie, R. (2013). Research Methods for Business: A Skill Building Approach. Sixth Edition. New York: Wiley.

Siregar, B., Suripto, B., Hapsoro, D., Lo, E. W., \& Biyanto, F. (2013). Akuntansi Manajemen. Jakarta: Salemba Empat.

Siregar, B., Suripto, B., Lo, E. W., Herowati, E., Kusumasari, L., \& Nurofik. (2016). Akuntansi Biaya. Edisi 2. Jakarta: Salemba Empat.

Subagyo, J. (2011). Metode Penelitian (Dalam Teori dan Praktik). Jakarta: Rineka Cipta.

Sugiyono. (2014). Metode Penelitian Kuantitatif, Kualitatif, dan $R \& D$. Bandung: Alfabeta.

Sulaiman, M., Ahmad, N. N., \& Alwi, N. M. (2005). Is standard costing obsolete? Empirical evidence from Malaysia. Managerial Auditing Journal, Vol. 20 Iss 2, 109-124.

Syahril, \& Hasanuddin. (2017). Implementasi Teknologi Software As A Service (SAAS) Untuk Menentukan Harga Pokok Produksi Aktual Menggunakan Metode Biaya Standar Pada UMKM Kota Pekanbaru. Prosiding CELSciTech, vol 2. ISSN: 2541-3023 (pp. 93100). Pekanbaru: CELSciTech.

Taqwim, M. A., \& Haryono. (2015). Upaya Peningkatan Profitabilitas Produksi dengan Menggunakan Metode Penentuan Biaya Standar. Jurnal LIPI. Vol. 5, No. 2. ISSN: 20884591, 6-13.

Tompodung, O. (2014). Analisis Net Profit Margin pada Usaha Laundry di Kota Manado. Jurnal EMBA; Vol.2, No.2; ISSN 2303-1174, 16821690.

Undang Undang Republik Indonesia Nomor 20 Tahun 2008 Tentang Usaha Mikro Kecil dan Menengah (UMKM)

Peraturan Gubernur Aceh Nomor 72 Tahun 2016 www.depkop.go.id (diakses pada tanggal 3 Mei 2018) www.diskop.acehprov.go.id (diakses pada tanggal 11 Mei 2018)

www.mediaaceh.com (diakses pada tanggal 13 Oktober 2018)

www.bukalapak.com (diakses pada tanggal 13 Oktober 2018) 
https://hargapangan.id (diakses pada tanggal 13

Oktober 2018) 